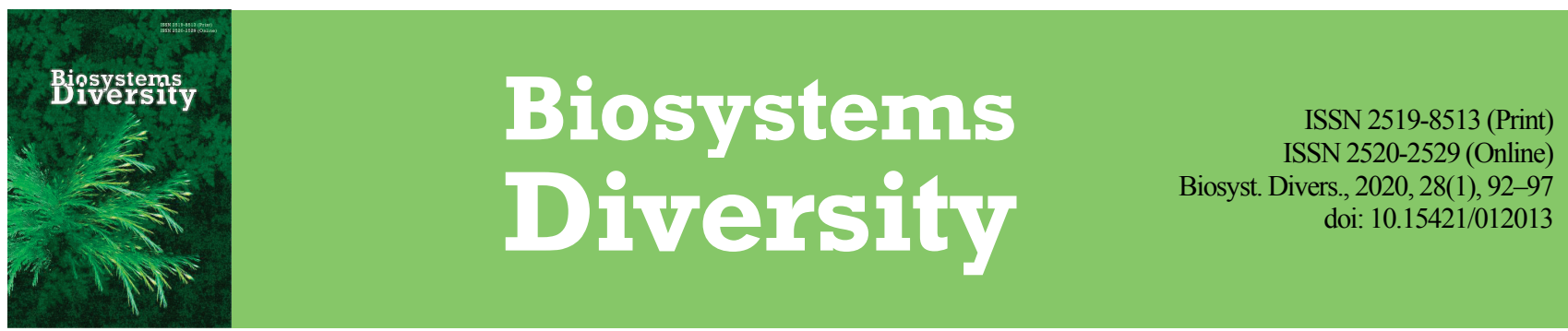

\title{
Trophic links of the chaffinch (Fringilla coelebs) in transformed forest ecosystems of North-Eastern Ukraine
}

\author{
A. B. Chaplygina*, O. Y. Pakhomov**, H. A. Yevtushenko***, V. V. Brygadyrenko** \\ *H. S. Skovoroda Kharkiv National Pedagogical University, Kharkiv, Ukraine \\ **Oles Honchar Dnipro National University, Dnipro, Ukraine \\ ***Luhansk Taras Shevchenko National University, Starobil's'k, Ukraine
}

Article info

Received 19.01.2020

Received in revised form 07.02.2020

Accepted 10.02.2020

H. S. Skovoroda Kharkiv National

Pedagogical University, Alchevskyst.

29, Kharkiv, 61002, Ukraine

Tel.: +38-050-61-81-896.

E-mail:iturdus@ukr.net

Oles Honchar Dnipro National

University, Gagarin ave., 72

Dnipro, 49010, Ukraine.

Tel.: +38-050-93-90-788.

E-mail:brigad@ua.fm

Luhansk Taras Shevchenko National University, Gogol' ave., 1, Starobil's' 92700, Ukraine. Tel.: +38-099-23-15-773. E-mail: evtushenko_lg@i.ua

\begin{abstract}
Chaplygina, A. B., Pakhomov, O. Y., Yevtushenko, H. A., \& Brygadyrenko, V. V. (2020). Trophic links of the chaffinch (Fringilla coelebs) in transformed forest ecosystems of North-Eastern Ukraine. Biosystems Diversity, 28(1), 92-97. doi:10.15421/012013
\end{abstract}

The chaffinch (Fringilla coelebs Linnaeus, 1758; Passeriformes, Fringillidae) is one of the most colourful forest species of birds living in Europe, West Asia and North Africa. The diet of this species was studied as a contribution to the conservation of the population of this species in transformed forests of the north-eastern part of Ukraine. Four forest ecosystems were studied: three model sites in oak forests, transformed under intensive recreation pressure, and one model site in a pine-oak forest. A total of 39 invertebrate taxa, dominated by Insecta $(93.0 \%)$ were found. The orders Coleoptera (32.6\%) and Lepidoptera $(63.5 \%)$ prevailed in the diet of finch nestlings, the highest number of taxa $(52.3-76.2 \%)$ was represented by phytophages. The phytophagous species also constituted the majority of the consumed prey items $(44.0-55.6 \%)$. Environmental conditions provided an important effect on the diet structure. The most favourable foraging conditions for the species were found in protected natural areas. According to the analysis, the finch foraging efficiency was similar in all the studied sites. The highest biodiversity indices were found in a protected area of Homilshanski Forests National Nature Park. Results of the research have indicated the crucial role of Fringilla coelebs in the population management of potentially dangerous agricultural pests.

Keywords: transformed areas; trophic groups; zoophages; phytophages; saprophages.

\section{Introduction}

The increasing rate of anthropogenic environmental changes, recorded since the second half of the XX century has led to the formation of urban coenoses (Blinkova \& Shupova, 2017). Ecosystem monitoring can be carried out by ecological indicators to preserve and manage the natural environment. Since it is impractical to monitor all ecosystem components, a few individual species or groups of species can be used as indicators of wider conditions. To monitor changes, birds are often used, since their mobility makes them convenient indicators of the environment (Gregory et al., 2003; Blair \& Johnson, 2008; Bulakhov et al., 2008; Chaplygina et al., 2019). Bioindicators are also the best tools to measure the progress made in biodiversity conservation, to assess the impacts and threats to biodiversity, to evaluate sustainable use of biodiversity (Chaplygina, 2000, 2009; Dranga et al., 2016; Gorlov et al., 2016). Birds are excellent bioindicators for the health of the environment and ecological change. Generally, birds have been used as indicator species for a range of environmental parameters. They act as biodiversity indicators for a number of reasons (Peach et al., 2004; Sobolev et al., 2017; Matsyura, 2018). The cause-and-effect link between an environmental change and birds is a direct and simple one.

Therefore, study of the status of insectivorous passerines in natural communities, exposed to a growing anthropogenic pressure, is one of the main objectives in contemporary ornithology (Hernández, 2009; Assandri et al., 2017; Koshelev et al., 2020).

The chaffinch (Fringilla coelebs Linnaeus, 1758) is a common insectivorous bird and a principal contributor to forest ecosystem communities of the temperate climate zone (Browne, 2004; Amar et al., 2006; Baillie et al., 2006; Domokos \& Domokos, 2016; Ramdani et al., 2019). It is also a migrant of global conservation concern (Bern Convention) and studies on the foraging ecology of the species will defini- tely assist in its conservation. It has been already revealed that habitat conditions of the chaffinch are crucial for the successful breeding and stability of its population in forests of England (Whittingham et al., 2001; Macleod et al., 2004), Turkey, Germany (Bergen \& Abs, 1997; Batary et al., 2014), Sweden (Felton et al., 2016), Romania (Domokos \& Domokos, 2016), Spain (Moreno-Rueda \& Pizarro, 2009; Peris \& Montelongo, 2014) and North East Algeria (Ramdani et al., 2019). The role of artificial light and noise for the finches when they search for food has also been studied (Quinn et al., 2006; Kempenaers et al., 2010). The latter is especially vital for the North-Eastern Ukraine, where the natural communities experience strong transformation (Brygadyrenko, 2015a, 2015b; Chaplygina et al., 2016a, 2016b, 2018). In addition, the knowledge of foraging patterns of insectivorous birds is important to prevent outbreaks of arthropods, being potential carriers of dangerous human diseases (James et al., 2011; Lommano et al., 2014; Bulakhov et al., 2015; Brobi et al., 2017), and to mitigate outbreaks of forestry and agricultural pests (Faly \& Brygadyrenko, 2014; Chaplygina et al., 2015; Caprio \& Rolando, 2017). It also gives an opportunity to control bird flocks which may otherwise destroy part of the harvest (Whittingham et al., 2001; Paralikidis et al., 2009). The chaffinch is known as a distributor of seeds of wild plants (zoochory) (Heleno et al., 2010; Perea \& Gil, 2014).

The high number of chaffinches in the forests of North-Eastern Ukraine allows us to consider it as a subdominant species (Chaplygina \& Savinskaya, 2016). Its biotope is diverse, including man-made landscapes (parks, orchards, gardens, boulevards, cemeteries); light oak forests; birch, willow and pine groves; flooded non-dense forests and islandtype forests in grasslands. F. coelebs tends to avoid large wet dark coniferous forests, restricting its habitats to their edges (Fesenko \& Bokotej, 2002). The timing of migrations of this bird (Nadtochiy \& Chaplygina, 2010) and the characteristics of their nest locations in Ukraine have 
been studied as well (Zimaroeva et al., 2015). The some researchers suggest that foraging patterns of the species can determine the management and conservation of the bird diversity in natural and transformed areas (Macleod et al., 2004; Amrhein, 2013; Korňan \& Adamík, 2017). Changes in habitats at nesting sites are potential causes of a decrease in the number of birds during nesting (Kirby et al., 2005; Paker et al., 2014). Consequently, they lead to the decline in invertebrates and the loss of feeding habitats for ground-foraging birds (Chaplygina, 2016; Markova, 2016; Chaplygina et al., 2019). One of the ways to support the species number and improve the foraging and distribution conditions is suburban river catchments, proposed in South Africa (Suri et al., 2017). The some scientists recommend planting shrubs and trees that have fruits and berries (Vanderhoff \& Eason, 2008; Jackson \& Kannan, 2018).

The author has already studied chaffinches in the forest-steppe zone of Ukraine in comparison with other species of finches (Kryvitsky \& Chaplygina, 2010). However, the diet of this bird in transformed areas requires more thorough investigation as it is the main factor that limits the species number.

The aim of this study is to make a qualitative and quantitative analysis of the diet structure and foraging pattern of the chaffinch to reveal trophic links and enhance the conservation of populations of this species in the transformed ecosystems of North-Eastern Ukraine.

\section{Materials and methods}

The research was carried out over the period 2010-2019, in the forest-steppe zone of Left-bank Ukraine (Kharkiv and Sumy regions). The diet structure of the nestlings was studied in an upland oak forest of Homilshanski Forests National Nature Park (Zmiiv District), in a forest park of Kharkiv, in a pine-oak forest of Hetmanskyi National Nature Park (Okhtyrka District), and in Vakalivshchyna Area (Sumy Region). According to Gensiruk's classification (2002), three trial plots, selected in the oak forests, were characterized by different stages of recreational digression (transformed as a result of heavy recreation pressure). The fourth trial plot was located in a pine-oak forest.

Trial plot 1 (TP1) is situated far from settlements, on the eastern bedrock bank of the Psel River in Vakalivshchyna Area and is represented by an oak forest mixed with some maple and linden trees. The crown closure makes up circa $85 \%$, and the proportion of damaged trees does not exceed $10 \%$ of their total number. The understory and shrub layers, without traits of noticeable damage, are typical for the habitat. The grassy cover is mainly undisturbed and typical for this forest type. In some areas, excessive development of forest herbs is observed, due to the falling of overmature trees. The forest floor is undisturbed and thick. The recreational coefficient of the site, based on the area of forest paths, comprised 5\%. Trial plot 1 (TP 1) has the first stage of recreational digression.

Trial plot 2 (TP 2) is located within a recreational zone of Homilshanski Forests National Nature Park, in the vicinities of research sites of H. S. Skovoroda Kharkiv National Pedagogical University and Karazin Kharkiv National University. This area is exposed to intensive recreation pressure during the bird breeding season. The forest includes damaged and diseased trees (about 35\%); the crown closure is about $70 \%$. The understorey and shrub layers are present but poorly differentiated. The grassy layer is partly disturbed; projective cover reaches $85 \%$ in some places. The forest floor is slightly disturbed. Forest paths cover up to $30 \%$ of the site. This model site has the $3 \mathrm{~d}$ stage of recreation digression, and the management of recreation pressure is required.

Trial plot 3 (TP 3) is in the forest park of Kharkiv City. It is a predominantly natural upland oak forest with a small admixture of artificially planted species, located in the interfluve of the Lopan and Kharkiv rivers. The crown closure is circa $60 \%$. The species, typical for the forest edge, as well as meadow, riparian, aquatic, and ruderal plants are recorded. There is an extended network of forest paths and roads, used for jogging. Increased recreation pressure leads to the expansion of open glades and the increasing density of paths. The maple Acer negundo forms dense thickets at the forest edge; in some places, garbage dumps can be found. The number of ruderal species increases as one approaches the forest border. The site has the 4 th level of recreational digression.

Trial plot 4 (TP 4) is situated in Hetmanskyi National Nature Park, in a pine forest near the villages of Kamianka and Klymetovo, in the area called "Lytovskyi Bir". The oak-pine and maple-linden-oak woodlands near Kamianka have slight signs of human-caused disturbance; diseased trees are found; the crown closure is circa $20 \%$. The understory and shrub layer are typical for the habitat; $5-20 \%$ of the trees have insignificant damages. The grassy layer includes meadow grasses (5-10\%), which is not typical for this type of the forest. The forest floor is slightly disturbed. The area of paths is not extensive and covers up to $10 \%$ of the model site. In the section, lying in Lytovskyi Bir, the area of paths exceeds $20 \%$. In July-August, the recreation pressure increases due to a high number of visitors. However, most bird species finish the breeding season before that time. The site has the third level of recreational digression.

A total of 52 chaffinch nests with 161 nestlings were inspected and 465 food pellets were collected. Of 838 invertebrate specimens, found in the trial plot, 110 (from 38 nestlings) in the oak forest TP 1, 138 (taken from 46 nestlings) were in the oak forest TP 2, 120 (from 35 nestlings) in the oak forest TP3 and 97 (from 42 nestlings) in the pine-oak forest TP 4.

The research was carried out from May 25th to June 15th (period 2010-2017) in the first half of the day. The nestling diet was investigated by applying neck ligatures to 5- to 8-day-old chicks (Malchevskij $\&$ Kadochnikov, 1953). The forage samples were fixed in a $70 \%$ soluteon of ethanol, and the arthropods were further identified in the laboratory. All the invertebrates were identified to the species, genus or family (in case of significant damage) by Associate Professor PhD Viktor Gramma by standard methods, using reference books. Similarity coefficients in the species composition of the invertebrates, found in the diet in different sites, were calculated using the formulas of Jaccard $(\mathrm{Cj}=$ $100 \times j /(a+b-j))$ and Sorensen $(C s=100 \times 2 j /(a+b))$, where $j-$ the number of invertebrate species found in both groups, $\mathrm{a}-$ the number of species in the first group, $b$ - the number of species in the second group. These coefficients ranged from 0 (no similarity between compared parameters) to 1 (complete similarity).

\section{Results}

In forest biogeocenoses, the chaffinch, as a representative of open nest birds, can collect food from various tree species. Moreover, the most important thing for this species is not the species composition of the vegetation, but the architectonics of the crown of the stand. In the nesting period, the finch prefers to collect food on trees and on the ground in the open parts of the forest litter, sometimes on the undergrowth and shrubs. When feeding and nesting on different species of trees, birds choose the same microstations: strong, rigid branches, mostly of the first or third order (Fig. 1). The most inaccessible for birds are the final branches on the periphery and top of the trees, since they rarely use the maneuver of "suspension" and "throw into the air." The trophic connections of birds are mainly similar when feeding on trees and land. In the crown of trees, the chaffinch moves along thick horizontal branches with lateral steps, jumps and acrobatics, pecking food from the surrounding branches and leaves, mainly with the help of "reaching out".

Our research revealed trophic links of the chaffinch with 39 taxa of invertebrate animals (Table 1). Representatives of Insecta $(93.0 \%$; $n=$ 838) constituted an absolute majority, while Arachnida (4.3\%), Malacostraca (1.7\%) and Diplopoda (1.0\%) were found in smaller percentages (Fig. 2a). The among insects, representatives of Coleoptera predominated $(32.6 \% ; \mathrm{n}=768)$, including Curculionidae $(65.4 \% ; \mathrm{n}=254)$, as well as Lepidoptera $(28.2 \% ; \mathrm{n}=768)$, with Noctuidae dominating $(56.8 \% ; \mathrm{n}=220)$. Hymenoptera $(16.2 \% ; \mathrm{n}=768)$, Diptera $(14.2 \%)$ and Hemiptera (8.5\%), Neuroptera $(0,4 \%)$ had a lower value (Fig. $2 b)$. Chaffinches pick up Lepidoptera caterpillars from grassy vegetation or from the ground surface in the period when they descend to the ground for pupation or fall on the grass due to strong wind. 


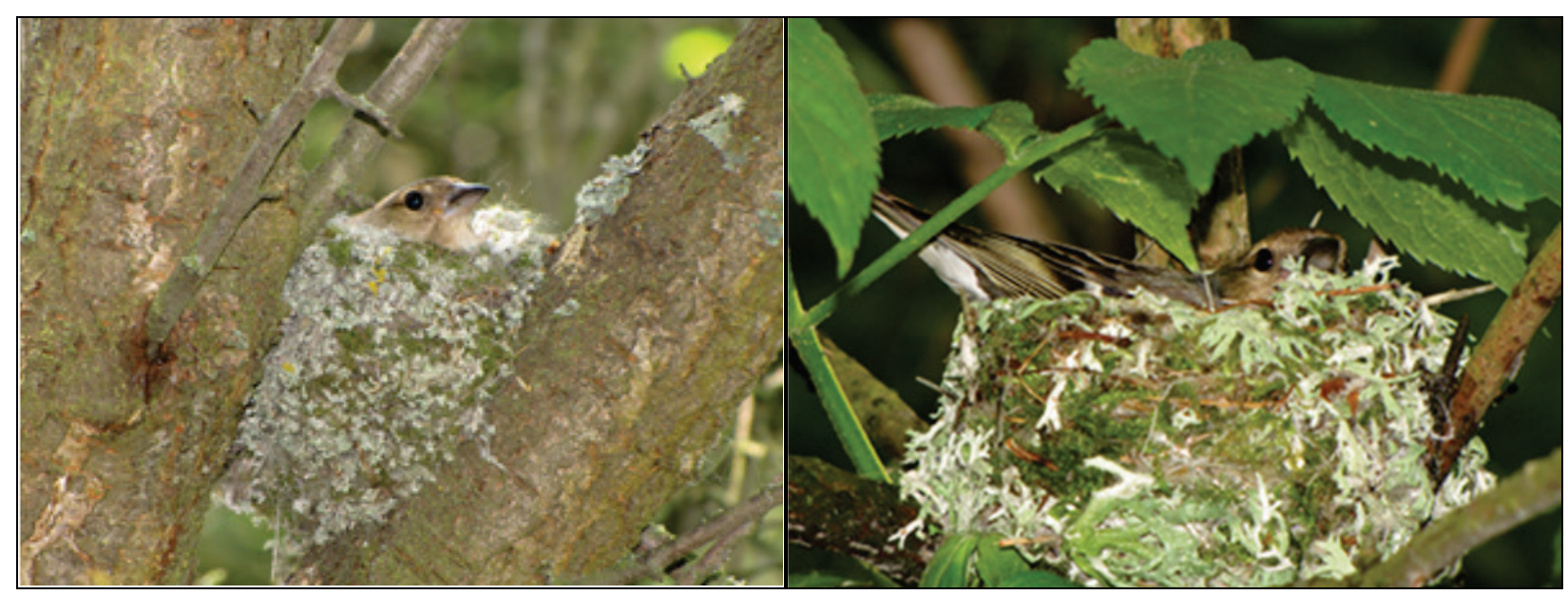

Fig. 1. Chaffinch nesting and feeding places

Table 1

Macrofauna species in the F. coelebs diet

\begin{tabular}{|c|c|c|c|c|c|c|c|c|c|}
\hline \multicolumn{3}{|c|}{ Taxon name } & \multirow{2}{*}{$\begin{array}{l}\text { Trophic } \\
\text { group }\end{array}$} & \multirow{2}{*}{ TP 1} & \multirow{2}{*}{ TP 2} & \multirow{2}{*}{ TP 3} & \multirow{2}{*}{ TP 4} & \multirow{2}{*}{$\begin{array}{c}\text { Total, } \\
\text { abs. }(\%)\end{array}$} & \multirow{2}{*}{ Notes } \\
\hline order & family & species & & & & & & & \\
\hline \multirow[t]{3}{*}{ Homoptera } & Aphididae & Aphididae sp. & $\mathrm{ph}$ & - & 8 & - & 36 & $44(5.3)$ & 34 imagoes, 10 larvae \\
\hline & Miridae & Miridae sp. & $\mathrm{ph}$ & - & 1 & - & - & $1(0.1)$ & imago \\
\hline & Acanthosomatidae & Elasmostethus sp. & $\mathrm{ph}$ & - & 2 & - & - & $2(0.2)$ & - 6 \\
\hline \multirow{12}{*}{ Hemiptera } & Acantnosomatuae & Elasmucha grisea (Linnaeus, 1758) & $\mathrm{ph}$ & - & 7 & - & - & $7(0.9)$ & -“- \\
\hline & & Palomena prasina (Linnaeus, 1761) & $\mathrm{ph}$ & - & - & - & 1 & $1(0.1)$ & larva \\
\hline & Pentatomidae & Pentatomidae sp. & $\mathrm{ph}$ & 5 & 2 & 3 & - & $10(1.2)$ & imagoes \\
\hline & & Eurydema oleracea (Linnaeus, 1758) & $\mathrm{ph}$ & 1 & - & - & - & $1(0.1)$ & larvae \\
\hline & Carabidae & Carabidae sp. & $\mathrm{z}$ & 2 & - & 2 & 2 & $6(0.7)$ & 4 imagoes, 2 larvae \\
\hline & Staphylinidae & Philonthus sp. & $\mathrm{z}$ & - & 5 & - & - & $5(0.6)$ & imagoes \\
\hline & & Oryctes nasicornis (Linnaeus, 1758) & s & - & 1 & - & - & $1(0.1)$ & pupa \\
\hline & Scarabaeidae & Anisoplia segetum (Herbst, 1783) & $\mathrm{ph}$ & 2 & - & 4 & 2 & $8(1.0)$ & imagoes \\
\hline & & A. austriaca (Herbst, 1783) & $\mathrm{ph}$ & - & 5 & - & - & $5(0.6)$ & -“- \\
\hline & Cantharidae & Malthinus flaveolus (Herbst, 1786) & $\mathrm{z}$ & - & 4 & - & - & $4(0.5)$ & imagoes \\
\hline & Cantuartuae & Cantharidae sp. & $\mathrm{z}$ & 3 & 5 & 4 & 4 & $16(1.9)$ & 12 imagoes, 4 larvae \\
\hline & & Agriotes gurgistanus (Faldermann, 1835) & $\mathrm{p}$ & - & 1 & - & - & $1(0.1)$ & imago \\
\hline \multirow{10}{*}{ Coleoptera } & & A. lineatus (Linnaeus, 1767 & $\mathrm{p}$ & - & 3 & - & - & $3(0.4)$ & -“- \\
\hline & & A. obscurus (Linnaeus, 1758) & $\mathrm{p}$ & 4 & 4 & 4 & 2 & $14(1.7)$ & -“- \\
\hline & Elateridae & A. ustulatus (Schaller, 1783) & $\mathrm{p}$ & - & 1 & - & - & $1(0.1)$ & $-“-$ \\
\hline & & Agriotes sp. & $\mathrm{p}$ & 3 & 4 & - & - & $7(0.8)$ & $-“$ \\
\hline & & Selatosomus aeneus (Linnaeus, 1758) & $\mathrm{p}$ & 2 & 3 & - & - & $5(0.6)$ & $-“-$ \\
\hline & & Chrysomela sp. & ph & 3 & 3 & - & 3 & $9(1.1)$ & $-“-$ \\
\hline & Chrysomelidae & Chrysomelidae sp. & $\mathrm{ph}$ & - & 3 & - & - & $3(0.4)$ & -“- \\
\hline & & Otiorrhinchus sp. & $\mathrm{ph}$ & 1 & - & - & - & $1(0.1)$ & $-“-$ \\
\hline & Curculionidae & Brachyderes incanus (Linnaeus, 1758) & $\mathrm{ph}$ & 2 & 3 & - & 2 & $7(0.9)$ & -“- \\
\hline & & Curculionidae sp. & $\mathrm{ph}$ & 25 & 50 & 58 & 25 & $158(19.0)$ & $-“-$ \\
\hline \multirow{5}{*}{ Neuroptera } & Chrysonidae & Chrysopidae sp. & $\mathrm{z}$ & - & 2 & - & - & $2(0.2)$ & $-“-$ \\
\hline & Cnrysopidae & Chrysopa sp. & $\mathrm{z}$ & - & 1 & - & - & $1(0.1)$ & $-“-$ \\
\hline & Tenthredinidae & Tenthredinidae sp. & $\mathrm{ph}$ & 4 & 4 & 4 & 4 & $16(2.0)$ & 8 imagoes, 8 larvae \\
\hline & Ichneumonidae & Ichneumonidae sp. & $\mathrm{z}$ & - & 7 & - & 4 & $11(1.3)$ & imagoes \\
\hline & & Lasius niger (Linnaeus, 1758) & $\mathrm{z}$ & 10 & 2 & 1 & 1 & $14(1.7)$ & 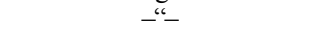 \\
\hline \multirow[t]{6}{*}{ Hymenoptera } & & L. fuliginosus (Latreille, 1798) & $\mathrm{z}$ & 8 & 2 & 3 & 1 & $14(1.7)$ & $-“-$ \\
\hline & Formicoidae & L. alienus (Förster, 1850) & $\mathrm{z}$ & 15 & 10 & - & - & $25(3.0)$ & - “- \\
\hline & & Lasius sp. & z & 14 & 6 & 7 & 7 & $34(4.1)$ & -“- \\
\hline & & Formica rufa (Linnaeus, 1761) & $\mathrm{z}$ & 3 & 9 & - & - & $12(1.4)$ & -“- \\
\hline & Tortricidee & Tortricidae sp. & $\mathrm{ph}$ & 5 & 3 & 4 & 4 & $16(1.9)$ & 6 imagoes, 5 pupae, 5 larvae \\
\hline & 10rtucidae & Tortrix viridana (Linnaeus, 1758) & $\mathrm{ph}$ & 3 & 3 & 3 & 4 & $13(1.6)$ & imagoes \\
\hline \multirow[t]{6}{*}{ Lepidoptera } & Nymphalidae & Liparidae sp. & $\mathrm{ph}$ & - & 2 & - & - & $2(0.2)$ & $-“$ \\
\hline & Noctuidae & Noctuidae sp. & $\mathrm{ph}$ & 30 & 25 & 50 & 20 & $125(14.9)$ & 102 imagoes, 3 pupae, 20 larvae \\
\hline & Geometridae & Geometridae sp. & ph & 8 & 8 & 40 & 8 & $64(7.6)$ & 20 imagoes, 44 larvae \\
\hline & Bibionidae & Bibionidae sp. & $\mathrm{ph}$ & 1 & - & - & - & $1(0.1)$ & imago \\
\hline & Opomyzidae & Opomyza florum (Fabricius, 1794) & $\mathrm{ph}$ & - & 1 & - & - & $1(0.1)$ & - - \\
\hline & Phoridae & Phoridae sp. & $\mathrm{s}$ & - & 2 & - & - & $2(0.2)$ & -“- \\
\hline \multirow[t]{4}{*}{ Diptera } & Tephritidae & Tephritidae sp. & $\mathrm{ph}$ & 18 & 10 & - & 10 & $38(4.5)$ & $-“$ \\
\hline & Sarcophagidae & Sarcophagidae sp. & $\mathrm{n}$ & - & 6 & - & - & $6(0.7)$ & 3 imagoes, 1 pupa, 2 larvae \\
\hline & Tachinidae & Tachinidae sp. & $\mathrm{z}$ & 8 & 6 & - & 7 & $21(2.5)$ & imago \\
\hline & & Diptera sp. & s & 10 & 2 & 20 & 10 & $42(5.0)$ & -“- \\
\hline Araneae & Araneae & Araneidae sp. & $\mathrm{z}$ & 10 & 10 & 6 & 10 & $36(4.3)$ & -“- \\
\hline Polydesmida & Polydesmidae & Polydesmus complanatus (Linnaeus, 1761) & s & - & 1 & - & - & $1(0.1)$ & - \\
\hline Julida & Julidae & Rossiulus kessleri (Lochmander, 1927) & s & - & - & 7 & - & $7(0.9)$ & -“- \\
\hline \multirow[t]{2}{*}{ Isopoda } & Porcellionidae & Porcellio scaber Latreille, 1804 & $\mathrm{~s}$ & - & 14 & - & - & $14(1.7)$ & $-“-$ \\
\hline & & Total & - & 200 & 251 & 220 & 167 & $838(100.0)$ & - \\
\hline
\end{tabular}

Notes: macrofauna trophic groups: $\mathrm{ph}$ - phytophages, $\mathrm{z}$ - zoophages, $\mathrm{p}$ - polyphages, $\mathrm{s}-$ saprophages, $\mathrm{n}-$ necrophages; TP $1-4-$ model sites, described in Materials and methods. 

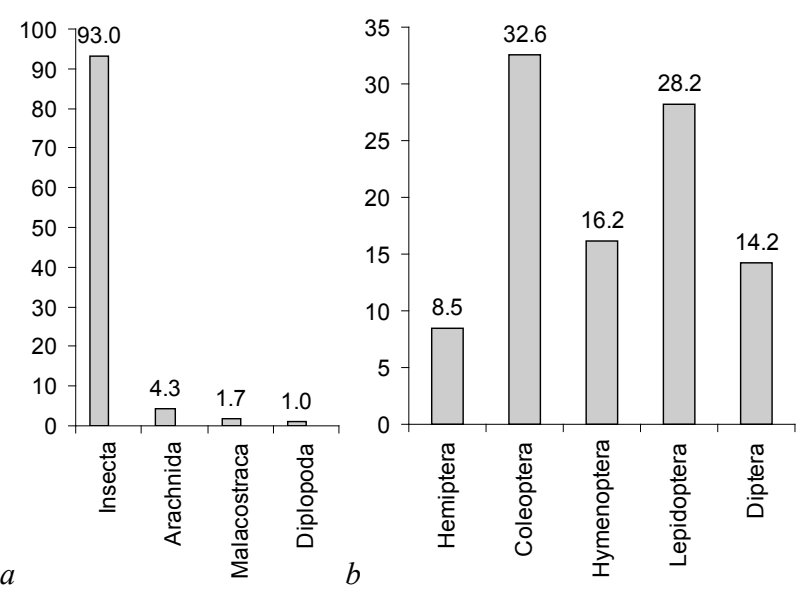

Fig. 2. Diversity of trophic links in the $F$. coelebs (data are summarized for all model plots, $\mathrm{n}=838$ ): $a$ - main groups of invertebrates; $b$ - main orders of insects; the ordinate is shown percentage in the total number $(\%)$
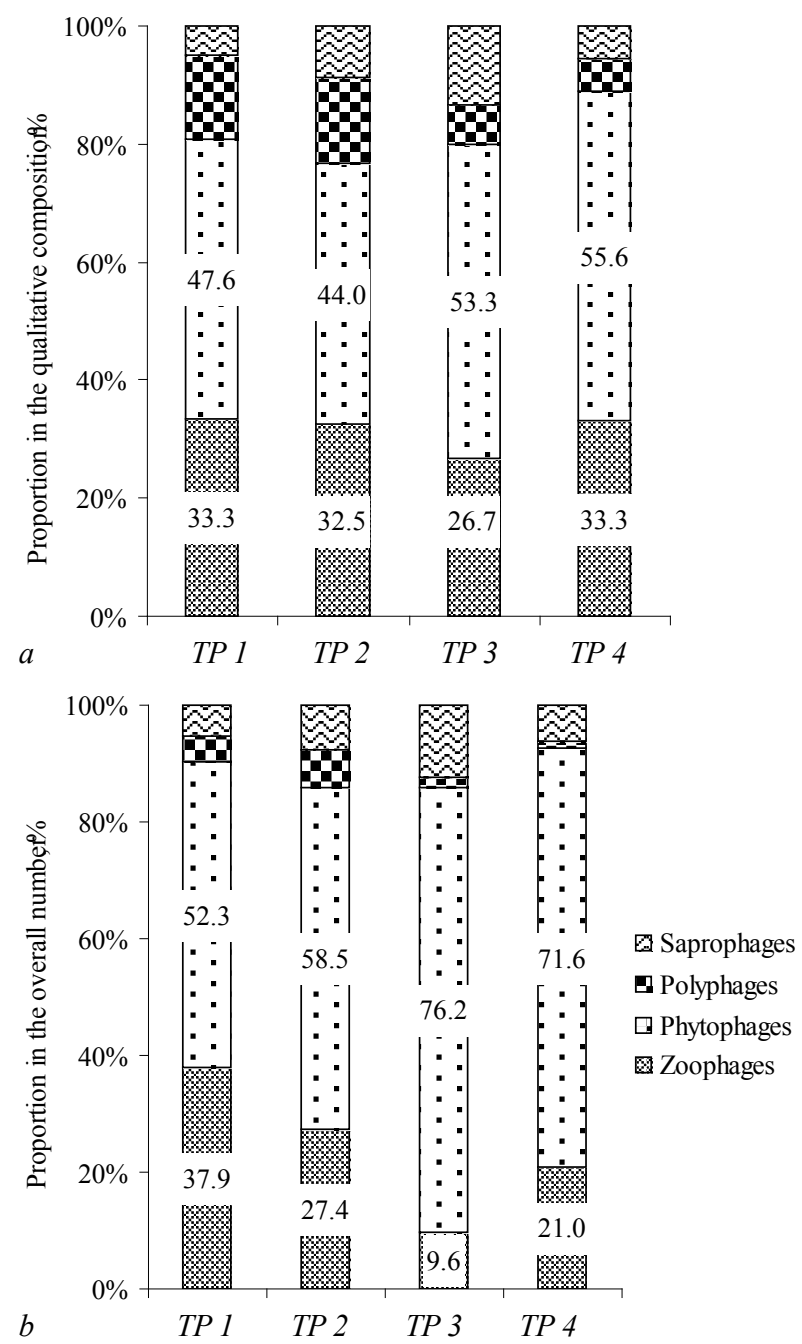

Fig. 3. Distribution of trophic groups of the $F$. coelebs in model sites $(\mathrm{n}=838)$ : $a$-proportion in the qualitative composition, $b$ - proportion in the overall number

The diet of the F. coelebs nestlings in all the trial plots (Fig. 3a), according to the proportion in the overall number of consumed species, was dominated by phytophages: from $44.0 \%$ (TP 2) and $47.6 \%$ (TP 1 ) to $53.3 \%$ (TP 3 ) and $55.6 \%$ (TP 4). Phytophages (Fig. 3b) dominated among prey items as well: $52.3 \%$ (TP 1) and $58.5 \%$ (TP 2) to $71.6 \%$ (TP 4 ) and $76.2 \%$ (TP 3 ). In the breeding period, the $F$. coelebs eliminate phytophages of forest plantations, in particular, the adult imagoes of Coleoptera with the majority of Curculionidae $(20.4 \%$; $=838)$ and larvae of Noctuidae (14.9\%) Lepidoptera had a noticeable share. Zoophages occupied the second place $(31.5 \%)$, significantly fewer polyphages $(10.3 \%)$, saprophages $(8.1 \%)$ and necrophages $(0.2 \%)$. The dominance of phytophages among forage objects indicates the significant role of the $F$. coelebs in regulating the number of phytophages of forest ecosystems. Thus, $F$. coelebs can undoubtedly be classified as an important insectivorous bird.

Analysis of average values of the indices of the trophic diversity of F. coelebs in different plots indicates its increase in the rows: nature reserve areas (TP 2 and 4), low- (TP 1) and highly transformed oak forest (TP 3). The highest number of taxonomic objects in the food of chaffinches' chicks was found in TR 2, where the highest values in all the indices of biodiversity: Margalef -6.20 , Menchinick - 2.25, Shannon3.11. In other plots, the diversity indices decrease with increase in the level of recreation. In TP 3 oak forest the indices were the lowest: Margalef -2.78 , Menchinick -1.08 , Shannon -2.13. Balance according to Macintosh and Pielou indicates evenness of selecting food objects in oak forests TP 1, 2 and 4, by contrast to oak forest TP 3 (Table 2).

Table 2

Indices of diet diversity of the $F$. coelebs in model sites of North-Eastern Ukraine

\begin{tabular}{lllll}
\hline \multicolumn{1}{c}{ Parameters } & TP 1 & TP 2 & TP3 & TP4 \\
\hline Margalef index & 4.15 & 6.20 & 2.78 & 3.73 \\
Manhinick index & 1.62 & 2.25 & 1.08 & 1.56 \\
Shannon index & 2.81 & 3.11 & 2.13 & 2.56 \\
Simpson dominance index & 0.89 & 0.86 & 0.93 & 0.88 \\
Simpson diversity index & 1.12 & 1.17 & 1.07 & 1.13 \\
Berger-Parker dominance index & 0.15 & 0.20 & 0.26 & 0.22 \\
McIntosh dominance index & 0.78 & 0.78 & 0.63 & 0.73 \\
McIntosh evenness & 0.91 & 0.88 & 0.79 & 0.86 \\
Pielou evenness & 2.06 & 2.02 & 1.77 & 1.96 \\
\hline
\end{tabular}

Table 3

Invertebrate similarity in the $F$. coelebs diet in model sites of North-Eastern Ukraine

\begin{tabular}{lccc}
\hline \multirow{2}{*}{ Pair of model sites } & Number of & \multicolumn{2}{c}{ Similarity index } \\
\cline { 3 - 4 } & invertebrate species & Jaccard & Sorensen \\
\hline TP 2 - TP 1 & 19 & 0.69 & 0.76 \\
TP 1 - TP 4 & 19 & 0.72 & 0.84 \\
TP 2 - TP 4 & 17 & 0.45 & 0.62 \\
TP 2 - TP 3 & 13 & 0.34 & 0.51 \\
TP 1 - TP 3 & 12 & 0.63 & 0.67 \\
TP 4 - TP 3 & 11 & 0.64 & 0.68 \\
\hline
\end{tabular}

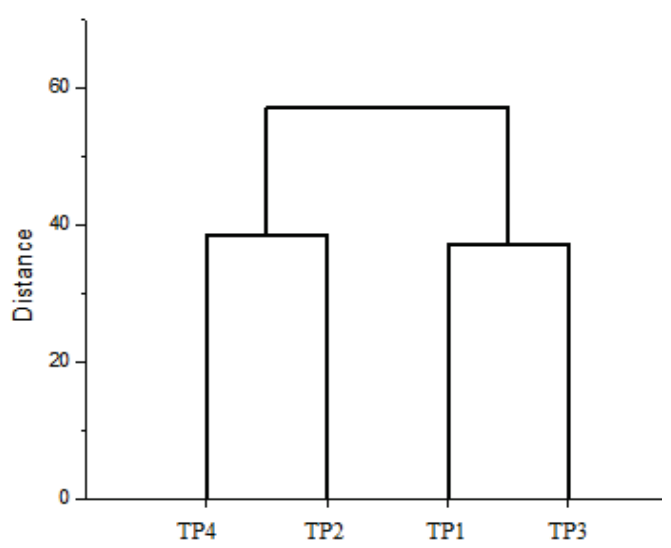

Fig. 4. Similarity of trophic links of F. coelebs in studied sites of North-Eastern Ukraine

Analysis of the similarity of diversity of trophic relations of chicks of $F$. coelebs indicates the highest similarity by 19 species of invertebrates in oak forests TP 1 and 2, Jaccard and Sørensen indices equaled 0.69 and 0.76 respectively in oak forest TP 1 and 4 . Indices of Jaccard and Sørensen equaled 0.72 and 0.84 , respectively (Table 3 ). In general the analysis of the average parameters of the species diversity of the diet of 
F. coelebs indicates significant similarity of the diet in different ecosystems and evenness of use of the bird's food objects. This explains the wide distribution and abundance of $F$. coelebs on different plots the species being undemanding in the location of nests (Fig. 4).

\section{Discussion}

In the trophic relations of chaffinch and common species of birds of forest ecosystems, the highest values of indices of similarity were found with Erithacus rubecula (Linnaeus, 1858): 0.25 - Jaccard, 0.47 - Sørensen. In general, low values of the mentioned indices represent absence of overlapping of the trophic niches of $F$. coelebs with common species of birds of forest ecosystems of North-Eastern Ukraine (Chaplygina, 2016; Chaplygina et al., 2016a, 2016b, 2018, 2019). Dominance of phytophage insects in the diet of $F$. coelebs and their high share in the forest park (TP3) indicates the possibility of involvement of the birds in forest plantations of urban landscapes.

In the trophic relations of $F$. coelebs during the nesting and pre-nesting periods, the dominance of Curculionidae in Belarus (Domancevich, 2017) and Leningrad Oblast (Prokofieva, 1963) was discovered. In Dnipropetrovsk Oblast (Bulakhov et al., 2015), the insects also dominated (92.0\%), among which lepidopterans (50.3\%) and coleopterans (27.8\%) dominated. Also, $7.9 \%$ comprised of mollusks (2.7\%), earthworms (2.4\%), spiders (1.8\%) and Diplopoda (0.8\%). Oniscidae, Dorilaimidae and Acari accounted only for $0.1 \%$. Therefore, the birds are observed to have a certain specialization of nutrition, which somewhat limits the feeding activity of birds during adaptation to new types of food. However, in most territories, $F$. coelebs is considered one of the less specialized species among the forest Passeriformes, the high flexibility and broad diet range, and diversity of its ethological relations makes this species eurytopic and dominant in most natural and anthropogenically transformed ecosystems (Marochkina, 2004; Shemiakina, 2009).

\section{Conclusion}

The diet of $F$. coelebs in four forest ecosystems (three model sites in the oak forests, transformed under intensive recreation pressure, and one model site in a pine-oak forest consisted of 39 invertebrate taxa. In the diet of chaffinch, insects dominated (93.0\%). Coleoptera (32.6\%) and Lepidoptera (63.5\%) dominated among the insects, most of the species were represented by phytophages. Protected natural areas are most suitable for life of this species. The results of the research have indicated the crucial role of $F$. coelebs in the population management of potentially dangerous agricultural pests.

\section{References}

Amar, A., Hewson, C. M., Thewlis, R. M., Smith, K. W., Fuller, R. J., Lindsell, J. A., Conway, G., Butler, S. J., \& MacDonald, M. A. (2006). What's happening to our woodland birds? Long-term changes in the populations of woodland birds. BTO Research Report 169/RSPB Research Report 19.

Amrhein, V. (2013). Wild bird feeding (probably) affects avian urban ecology. In: Gil, D., \& Brumm, H. (Eds.). Avian urban ecology. Oxford University Press, Oxford. Pp. 29-38.

Assandri, G., Bogliani, G., Pedrini, P., \& Brambilla, M. (2017). Insectivorous birds as "non-traditional" flagship species in vineyards: Applying a neglected conservation paradigm to agricultural systems. Ecological Indicators, 80, 275-285.

Baillie, S. R., Marchant, J. H., Crick, H. Q. P., Noble, D. G., Balmer, D. E., Coombes, R. H., Downie, I. S., Freeman, S. N., Joys, A. C., Leech, D. I., Raven, M. J., Robinson, R. A., \& Thewlis, R. M. (2006). Breeding birds in the wider countryside: Their conservation status 2005. Research Report 435. BTO, Thetford.

Batáry, P., Fronczek, S., Normann, C., Scherber, C., \& Tscharntke, T. (2014). How do edge effect and tree species diversity change bird diversity and avian nest survival in Germany's largest deciduous forest? Forest Ecology and Management, 319(7), 44-50

Bergen, F., \& Abs, M. (1997). Verhaltensökologische Studie zur Gesangsaktivität von Blaumeise (Parus caeruleus), Kohlmeise (Parus major) und Buchfink (Fringilla coelebs) in einer Großstadt. Journal of Omithology, 138(4), 451-467.

Blair, R. B., \& Johnson, E. M. (2008). Suburban habitats and their role for birds in the urban-rural habitat network: Points of local invasion and extinction? Landscape Ecology, 23(10), 1157-1169.
Blinkova, O., \& Shupova, T. (2017). Bird communities and vegetation composition in the urban forest ecosystem: Correlations and comparisons of diversity indices. Ekológia (Bratislava), 36(4), 366-387.

Brobey, B., Kucknoor, A., \& Armacost, J. (2017). Prevalence of Trichomonas, Salmonella, and Listeria in wild birds from Southeast Texas. Avian Diseases, 61(3), 347-352.

Browne, S. J. (2004). Some aspects of chaffinch Fringilla coelebs biology, based on an analysis of individuals ringed during 1991 to 2003 in Norfolk, England. Ringing and Migration, 22(2), 75-82.

Brygadyrenko, V. V. (2015a). Community structure of litter invertebrates of forest belt ecosystems in the Ukrainian steppe zone. International Journal of Environmental Research, 9(4), 1183-1192.

Brygadyrenko, V. V. (2015b). Influence of moisture conditions and mineralization of soil solution on structure of litter macrofauna of the deciduous forests of Ukraine steppe zone. Visnyk of Dnipropetrovsk University, Biology, Ecology, 23(1), 50-65.

Bulakhov, V. L., Gubkin, A. A., Ponomarenko, O. L., \& Pakhomov, O. Y. (2008). Biologichne riznomanittya Ukrainy. Dnipropetrovska Oblast'. Ptahy: Negorobcepodibni (Aves: Non-Passeriformes) [Biological diversity of Ukraine. Dnipropetrovsk Region. Aves: Non-Passeriformes]. Dnipropetrovsk University Press, Dnipropetrovsk (in Ukrainian).

Bulakhov, V. L., Gubkin, A. A., Ponomarenko, O. L., \& Pakhomov, O. Y. (2015). Biologichne riznomanittya Ukrainy. Dnipropetrovska Oblast'. Ptahy: Gorobcepodibni (Aves: Passeriformes) [Biological Diversity of Ukraine. Dnipropetrovsk Region. Aves: Passeriformes]. Dnipropetrovsk University Press, Dnipropetrovsk (in Ukrainian).

Caprio, E., \& Rolando, A. (2017). Management systems may affect the feeding ecology of great tits Parus major nesting in vineyards. Agriculture, Ecosystems and Environment, 243, 67-73.

Chaplygina, A. B. (2000). K voprosu o biotsenoticheskoy roli ptits v ekosistemakh (na primere roda Turdus) [On the issue of a biocoenotical role of birds in ecosystems (by the example of the genus Turdus)]. In: Birds of the Seversky Donets basin. Proceedings of the 6th and 7th conference "Study and protection of birds of the Seversky Donets basin". Donetsk. Pp. 51-57 (in Russian).

Chaplygina, A. B. (2009). Osoblyvosti roztashuvannya gnizd drozdiv rodu Turdus v transformovanyh landshaftah Pivnichno-Shidnoyi Ukrayini [Characteristics of nest locations of thrushes of the genus Turdus in transformed landscapes of North-Eastern Ukraine]. Berkut, 18, 131-138 (in Ukrainian).

Chaplygina, A. B. (2016). The consortial relations of eurasian blackcap (Sylvia atricapilla L.) in the forest cenoses of Left bank Ukraine. Studia Biologica, 10(1), 99-110.

Chaplygina, A. B., \& Savinskaya, N. O. (2016). Sovremennoe sostoyanie ornitofauny transformirovannyh landshaftov Severo-Vostochnoy Ukrainy na primere Muscicapidae i Turdidae [Current status of the avifauna of transformed landscapes of North-Eastern Ukraine by the example of Muscicapidae and Turdidae]. Russian Ornithological Journal, 25, 615-647 (in Russian).

Chaplygina, A. B., Gramma, V. N., Bondarets, D. I., \& Savynska, N. O. (2015). Arthropods in trophic-cenosis structure of collared flycatcher consortium in conditions of forest ecosystems of North-Eastern Ukraine. Visnyk of Dnipropetrovsk University, Biology, Ecology, 23(1), 74-85.

Chaplygina, A. B., Pakhomov, O. Y., \& Brygadyrenko, V. V. (2019). Trophic links of the song thrush (Turdus philomelos) in transformed forest ecosystems of North-Eastern Ukraine. Biosystems Diversity, 27(1), 51-55.

Chaplygina, A. B., Savynska, N. O., \& Brygadyrenko, V. V. (2018). Trophic lincs of the spotted flycatcher, Muscicapa striata, in transformed forest ecosystems of North-Eastern Ukraine. Baltic Forestry, 24(2), 304-312.

Chaplygina, A. B., Yuzyk, D. I., \& Savynska, N. O. (2016a). The robin, Erithacus rubecula (Passeriformes, Turdidae), as a component of autotrophic consortia of forest cenoses, Northeast Ukraine. Vestnik Zoologii, 50(4), 369-378.

Chaplygina, A. B., Yuzyk, D. I., \& Savynska, N. O. (2016b). The robin, Erithacus rubecula (Passeriformes, Turdidae), as a component of heterotrophic consortia of forest cenoses, Northeast Ukraine. Part 2. Vestnik Zoologii, 50(6), 493-502.

Domancevich, D. G. (2017). Pitanie fonovyh lesnyh vidov pereletnyh vorob'inoobraznyh ptic $\mathrm{v}$ rannevesennij period [Nutrition of background forest species of migratory passerine birds in the early spring]. Zhurnal Belorusskogo Gosudarstvennogo Universiteta, Biologija, 3, 101-112 (in Russian).

Domokos, E., \& Domokos, J. (2016). Bird communities of different woody vegetation types from the Niraj Valley, Romania. Turkish Journal of Zoology, 40, 734-742.

Dranga, A. O., Gorlov, P. I., Matsyura, A. V., \& Budgey, R. (2016). Breeding biology of rook (Corvus frugilegus) in the human transformed steppe ecosystems (the case of Botievo Wind Farm). Biological Bulletin of Bogdan Chmelnitskiy Melitopol State Pedagogical University, 6(1), 41-62.

Faly, L. I., \& Brygadyrenko, V. V. (2014). Patterns in the horizontal structure of litter invertebrate communities in windbreak plantations in the steppe zone of the Ukraine. Journal of Plant Protection Research, 54(4), 414 420.

Felton, A., Hedwall, P. O., Lindbladh, M., Nyberg, T., Felton, A. M., Holmström, E., Wallin, I., Löf, M., \& Brunet, J. (2016). The biodiversity contribution of 
wood plantations: Contrasting the bird communities of Sweden's protected and production oak forests. Forest Ecology and Management, 365, 51-60.

Fesenko, H. V., \& Bokotej, A. A. (2002). Ptahy fauny Ukrainy: Pol'ovyj vyznachnyk [Birds of the Ukrainian fauna: Field reference book]. Novyj Druk, Kyiv (in Ukrainian).

Gensiruk, S. A. (2002). Lisy Ukrainy [Forests of Ukraine]. Scientific Organization Named after T. G. Shevchenko, Lviv (in Ukrainian).

Gorlov, P. I., Siokhin, V. D., \& Matsyura, A. V. (2016). Assessment of potential threats of wind farms for migratory birds in the south of Ukraine. Biological Bulletin of Bogdan Chmelnitskiy Melitopol State Pedagogical University, 6(3), 175-186.

Gregory, R. D., Noble, D., Field, R., Marchant, J., Raven, M., \& Gibbons, D. W (2003). Using birds as indicators of biodiversity. Ornis Hungarica, 12-13, $11-24$.

Hamer, K. C., Newton, R. J., Edwards, F. A., Benedick, S., Bottrell, S. H., \& Edwards, D. P. (2015). Impacts of selective logging on insectivorous birds in Borneo: The importance of trophic position, body size and foraging height. Biological Conservation, 188, 82-88.

Heleno, R. H., Ross, G., Everard, A., Memmott, J., \& Ramos, J. A. (2010). The role of avian "seed predators" as seed dispersers. Ibis, 153(1), 199-203.

Hernández, Á. (2009). Summer-autumn feeding ecology of pied flycatchers Ficedula hypolueca and spotted flycatchers Muscicapa striata: The importance of frugivory in a stopover area in North-West Iberia. Bird Conservation International, 19(3), 224

Jackson, J. L., \& Kannan, R. (2018). Avian frugivory in a fruiting mulberry tree (Morus rubra) in Arkansas. Journal of the Arkansas Academy of Science, 72(1), e10.

James, M. C., Furness, R. W., Bowman, A. S., Forbes, K. J., \& Gilbert, L. (2011) The importance of passerine birds as tick hosts and in the transmission of Borrelia burgdorferi, the agent of Lyme disease: A case study from Scotland. Ibis, 153(2), 293-302.

Kempenaers, B., Borgström, P., Loës, P., Schlicht, E., \& Valcu, M. (2010). Artificial night lighting affects dawn song, extra-pair siring success, and lay date in songbirds. Current Biology, 20(19), 1735-1739.

Kirby, W., Black, K., Pratt, S., \& Bradbury, R. (2005). Territory and nest-site habitat associations of spotted flycatchers Muscicapa striata breeding in Central England. Ibis, 147(2), 420-424.

Korňan, M., \& Adamík, P. (2017). Tree species preferences of foraging insectivorous birds in a primeval mountain mixed forest: Implications for management. Scandinavian Journal of Forest Research, 32(8), 671-678.

Koshelev, V. A., Pakhomov, O. Y., \& Busel, V. A. (2020). The formation of sclerophilic ornythocomplexes in the quarries in the south of Ukraine and their conservation prospects. Ecology, Environment and Conservation, 26(1), 411-419.

Kryvitsky, I. A., \& Chaplygina, A. B. (2010). Ecological and faunistic review of changes and the current state. Representatives finches birds in the Kharkiv Region. In: Birds of the Seversky Donets Basin. Materials of 15 Scientific Conference (Donetsk, 16-18 October 2009). Donetsk. Pp. 25-35 (in Russian).

Lommano, E., Dvořák, C., Vallotton, L., Jenni, L., \& Gern, L. (2014). Tick-borne pathogens in ticks collected from breeding and migratory birds in Switzerland. Ticks and Tick-Borne Diseases, 5(6), 871-882.

Macleod, C. J., Parish, D. M. B., \& Hubbard, S. F. (2004). Habitat associations and breeding success of the chaffinch Fringilla coelebs. Bird Study, 51(3) 239-247.

Malchevskij, A. S., \& Kadochnikov, A. S. (1953). A method of in vivo study of the nestlings' diet of insectivorous birds. Zoologicheskij Zhurnal, 32(2), 227-282.

Markova, A. O. (2016). Aggressive behaviour of robins Erithacus rubecula (Passeriformes, Muscicapidae) at watering places in the forest steppe zone of
Ukraine. Visnyk of Dnipropetrovsk University, Biology, Ecology, 24(2), 283-289.

Marochkina, E. A. (2004). Troficheskie i prostranstvennye otnoshenija vorob'inyh ptic v lesnyh biotopah Meshherskoj nizmennosti [Trophic and spatial relationships of passerines in forest biotopes of the Meshchera lowland]. Riazan' (in Russian).

Matsyura, A. V. (2018). Effectiveness of antiperching devices against the feral pigeons. Ukrainian Journal of Ecology, 8(2), 326-328.

Moreno-Rueda, G., \& Pizarro, M. (2008). Relative influence of habitat heterogeneity, climate, human disturbance, and spatial structure on vertebrate species richness in Spain. Ecological Research, 24(2), 335-344.

Nadtochiy, A. S., \& Chaplygina, A. B. (2010). Dolgovremennyie izmeneniya srokov prileta ptits v Harkovskuyu oblast [Long-term changes in timing of bird arrival in Kharkov region]. Branta, 13, 50-62 (in Russian).

Paker, Y., Yom-Tov, Y., Alon-Mozes, T., \& Barnea, A. (2014). The effect of plant richness and urban garden structure on bird species richness, diversity and community structure. Landscape and Urban Planning, 122, 186-195.

Paralikidis, N., Papageorgiou, N., Tsiompanoudis, A., \& Kontsiotis, V. (2009). Song thrush Turdus philomelos winter diet in Mediterranean habitats: A case study in Greece. Avocetta, 33, 109-111.

Peach, W. J., Robinson, R. A., \& Murray, K. A. (2004). Demographic and environmental causes of the decline of rural song thrushes Turdus philomelos in lowland Britain. Ibis, 146, 50-59.

Perea, R., \& Gil, M. V. L. (2014). Seed predation on the ground or in the tree? Size-related differences in behavior and ecology of granivorous birds. Acta Ornithologica, 49(1), 119-130.

Peris, S., \& Montelongo, T. (2014). Birds and small urban parks: A study in a high plateau city. Turkish Journal of Zoology, 38, 316-325

Prokofieva, I. V. (1963). Materialy po pitaniju zjablika y Leningradskoj oblast [Materials for finch nutrition in the Leningrad region]. Ecology of vertebrates of the Leningrad region. Uchenye Zapiski LSPI imeni A. I. Hercena. Leningrad. Vol. 230. Pp. 71-86

Quinn, J. L., Whittingham, M. J., Butler, S. J., \& Cresswell, W. (2006). Noise, predation risk compensation and vigilance in the chaffinch Fringilla coelebs. Journal of Avian Biology, 37(6), 601-608

Ramdani, K., Kouidri, M., Ouakid, M. L., \& Houhamdi, M. (2019). Breeding biology of the chaffinch Fringilla coelebs africana in the El Kala National Park (North East Algeria). Arxius de Miscellània Zoològica, 109-121.

Shemiakina, O. A. (2009). Troficheskie i prostranstvennye svjazi ptic v estestvennyh $\mathrm{i}$ antropogennyh mestoobitanijah [Trophic and spatial relationships of birds in natural and anthropogenic transformed habitats]. In: Behavior, animal ecology: Monographs, articles, reports. Ryazan’. Vol. 1. Pp. 151-294.

Sobolev, A., Gutyj, B., Grynevych, N., Bilkevych, V., \& Mashkin, Y. (2017). Enrichment of meat products with selenium by its introduction to mixed feed compounds for birds. Regulatory Mechanisms in Biosystems, 8(3), 417-422.

Suri, J., Anderson, P. M., Charles-Dominique, T., Hellard, E., \& Cumming, G. S. (2017). More than just a corridor: A suburban river catchment enhances bird functional diversity. Landscape and Urban Planning, 157, 331-342.

Vanderhoff, E. N., \& Eason, P. K. (2008). Comparisons between juvenile and adult american robins foraging for mulberry fruit. The Wilson Journal of Ornithology, 120(1), 209-213.

Whittingham, M. J., Bradbury, R. B., Wilson, J. D., Morris, A. J., Perkins, A. J., \& Siriwardena, G. M. (2001). Chaffinch Fringilla coelebs foraging patterns, nestling survival and territory distribution on lowland farmland. Bird Study, 48(3), 257-270

Zimaroeva, A., Zhukov, A., Ponomarenko, A., \& Matsura, A. (2015). Ecological niche modelling of Fringilla coelebs Linnaeus, 1758 (common chaffinch) using GIS tools. Romanian Journal of Biology - Zoology, 60(2), 135-146. 